\title{
Assessing the impact of financial crisis on bank performance: empirical evidence from Indonesia
}

\begin{abstract}
The paper seeks to examine the determinants of Indonesian banks profitability during the period 1990ï 2005. The empirical findings indicate that income diversification and capitalization are positively related to bank profitability, while size and overhead costs exert negative impacts. During the period under study, Indonesian banks seem to have been skimping on their resources, particularly during the pre-crisis and crisis periods. The impact of economic growth and banking sector concentration are positive during the pre-crisis and crisis periods. We find that the Asian financial crisis exerts negative and significant impact on the profitability of Indonesian banks, while Indonesian banks have been relatively more profitable during the pre-crisis compared to the post-crisis and crisis periods.
\end{abstract}

Keyword: Banks; Profitability; Indonesia 